\title{
Original
}

\section{PREVENTION OF THE SUPRAGINGIVAL}

\section{CALCULUS FORMATION BY MEANS OF}

\section{THE CALCULUS SPLINT}

\author{
Masao ONISI and Hiroaki OTANI \\ Department of Preventive Dentistry, School of Dentistry, \\ Tokyo Medical and Dental University
}

One of the most effective procedures for the recovery from the inflammative gingiva or keeping gingiva healthy is scaling off the calculus deposit from the tooth surfaces. Effect of the mechanical scaling, however, is apparently discontinuous and frequent scaling has technical limitation. Thus several agents have been tested for seeking better substitute that brings the continuous calculus-less circumstance by the tooth bed. The appropriate enzyms ${ }^{1,2,3,4,5,6,18)}$ which hydrolyse organic constituents of the calculus, acids? ${ }^{7,8)}$ ion exchange resin, ${ }^{90}$ complex formers, ${ }^{11,12)}$ adsorbent, ${ }^{13)}$ enzym inhibitors ${ }^{14)}$ and detergents ${ }^{15,17,18)}$ have been examined due to their own possibilities. Automatic tooth brushing, ${ }^{16)}$ several disinfectants ${ }^{17,18}$ and polymetaphosphate ${ }^{19)}$ were also concerned in respect on their biological activity. Few of the above agents, unfortunately however, possessed clinical test based on the critical evaluation of the result. Ennever et $\mathrm{al}^{20)}$ introduced the method of counting calculus surface index in this field for the clinical evaluation of the several inhibitors against the calculus formation. Schroeder and Marthaler ${ }^{21)}$ improved celluloid band method in order to study the calculus formation, and has made up the standard folien technique which can estimate the amount of calculus produced on a certain area of the foil for the certain period of time by weighing of the foil or determining $\mathrm{Ca}$ amount on the foil.

Onisi and Kondo ${ }^{22)}$ has found that longer application of a small acrylic splint covering the dentogingival area of lower front teeth is able to remove supra- and subgingival calculus. Toganoh and $\mathrm{Onisi}^{23)}$ applied on the inside of lower front teeth and the outside of upper molars of 30 patients of heavy calculus deposition and obtained good results. The present report concerns with the clinical test on the preventive effect of the dentogingival splint upon the calculus formation in situ. The whole report consists of two parts: the method of evaluation of the preventive effect and the clinical results of the splint applied.

Received for publication May 24, 1966. 


\section{PART I. ON THE EVALUATION METHOD OF THE SUPRAGINGINGIVAL CALCULUS FORMATION}

Because of a few references upon dynamic and static knowledges on the calculus formation, some preliminary studies are necessary for making up the rational method of the evaluation.

\section{MATERIALS AND METHODS}

Depend on the fact that the majority of chemical constituents of the calculus is calcium salts ${ }^{24}$ the calcium content of the deposit was measured in place of it. The calculus deposited for certain period of time was thoroughly scaled out from the surface of the clinical crown of teeth by a sickle type heavy scalor, carefully avoiding the bleeding from the adjacent gingiva, and then it was collected on a small peace of filter paper for analytical use (Toyo Roshi \#7). Calcium content in the obtained sample was first extracted in $5 \mathrm{ml}$ of $20 \%$ distilled $\mathrm{HCl}$ solution, and then acidity of the extract was adjusted to pH 5.5 by addition of $10 \%$ ammonia solution, and finally it was sedimented as Ca-oxalate and determined by means of the permanganometry.

Total number of persons examined were 297 adults, consisting of 234 males and 63 females and ranged from 16 to 63 year old. Specimens taken from the above subjects were 516 for the several purposes of experiments.

\section{RESULTS}

\section{Accumulated $\mathrm{Ca}$ amount in the deposits for the certain period of time}

It was tested in two ways, short and long term. After thorough cleaning of lower front teeth of 28 adults, consisting of 10 males and 18 females, deposition on $3-\longdiv { 3 }$ during 2, 5 and 7 days, and 4 and 12 weeks were collected, and Ca amount in each samples were then determined. The geometric means of $\mathrm{Ca}(\mathrm{mg})$ are surveyed on Table 1 . $\mathrm{Ca}$ amount in 7 day-deposit is almost double of that in 5 day-deposit. About $61 \%$ of deposition during 12 weeks was produced within 4 weeks, while $\mathrm{Ca}$ in 4 week-deposit was almost 4 times as much as that of 7 days.

2. Calculus formation on the areas, $3-\sqrt{3}$ and $\overline{1} \mid 1$ during 7 days.

Two groups consisting of 15 males each were compared in respect on the range where samples should be obtained from. The deposits on $\overline{3}-\sqrt{3}$ of one group and on

Table 1. Ca amount deposited for the certain period of time

\begin{tabular}{c|c}
\hline $\begin{array}{c}\text { Periods of time } \\
\text { for deposition }\end{array}$ & $\begin{array}{c}\text { Geometric means } \\
\text { from 28 subjects }\end{array}$ \\
\hline 2 days & $0.47 \mathrm{mg}$ \\
5 days & $0.65 \mathrm{mg}$ \\
7 days & $1.16 \mathrm{mg}$ \\
4 weeks & $4.15 \mathrm{mg}$ \\
12 weeks & $6.76 \mathrm{mg}$
\end{tabular}

Table 2. Ca amount in the deposit recovered from two different areas of lower front teeth; 3$\rceil-\overline{3}$ and $\overline{1} \mid \mathbf{1}$

\begin{tabular}{c|c|c|c}
\hline \multirow{2}{*}{ Subjects } & \multicolumn{2}{|c|}{ Area of sampling } & \multirow{2}{*}{ Rate $(\%)$} \\
\cline { 2 - 3 } & $3-\sqrt{3}$ & $1 / 1$ & \\
\hline $\begin{array}{c}\text { First group } \\
(15 \text { subjects) }\end{array}$ & $1.16 \mathrm{mg}$ & $0.75 \mathrm{mg}$ & $64.4 \%$ \\
$\begin{array}{c}\text { Second group } \\
\text { (another 15 subjects) }\end{array}$ & $1.93 \mathrm{mg}$ & $1.41 \mathrm{mg}$ & $73.1 \%$
\end{tabular}


\begin{tabular}{l|l}
1 & 1
\end{tabular} of another group were examined at first, and then each groups switched the range of sampling areas. From the results on Table 2, majority of $\mathrm{Ca}$ amount in a deposit recovered from $\overline{\cdot 3}-\sqrt{3}$ was found in the sample taken from $\overline{1} \mid \mathbf{1}$.

3. Two successive sampling from the same subjects

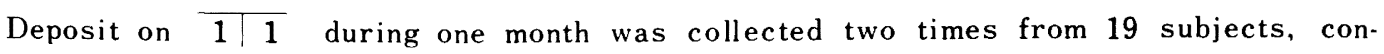
sisting of 5 males and 14 females, at the end of first and second month. The geometric means of first and second results were almost the same as shown in Table 3. Difference of both means was statistically insignificant. However, ratios of $\mathrm{Ca}$ amount in the first to the second samples of each subject are little wider as it is counted to be from 0.34 to 2.16 .

\section{Population pattern of $\mathrm{Ca}$ content in one month deposit}

It was examined at two groups in order to know the population pattern of samples for the statistical treatment. One is a group of 140 heavy depositors of calculus, employees of Edogawa Factory, Honshu Paper Company, and the other is a group of 138 persons of unconscious of calculus deposition, working at Tsurumi Factory, Toshiba Electric Company. Population pyramid of the both groups is illustrated on Fig. 1.

It was found that logarithmic $\mathrm{Ca}$ amount of samples were plotted fairly lineal against percent integrated frequency in probability scale, as shown on Fig. 2. The result indicates

Table 3. Ca amount in the specimens obtained from successive double sampling

\begin{tabular}{c|c|c|c}
\hline Order of sampling & Geometric means & Means in log. & $\begin{array}{c}\text { Standard errors } \\
\text { in iog. }\end{array}$ \\
\hline 1st month & $1.42 \mathrm{mg}$ & 0.152 & \pm 0.0589 \\
2nd month & $1.48 \mathrm{mg}$ & 0.170 & \pm 0.0642
\end{tabular}

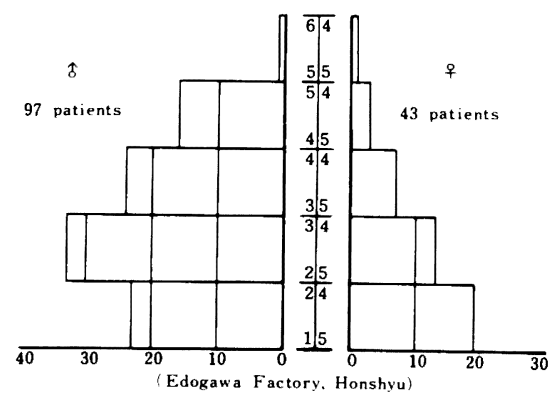

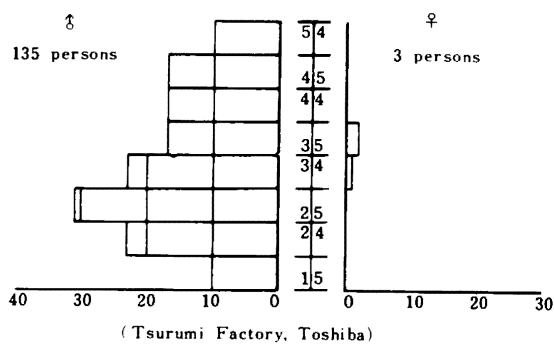

Fig. 1. Population pyramids of two groups of subject

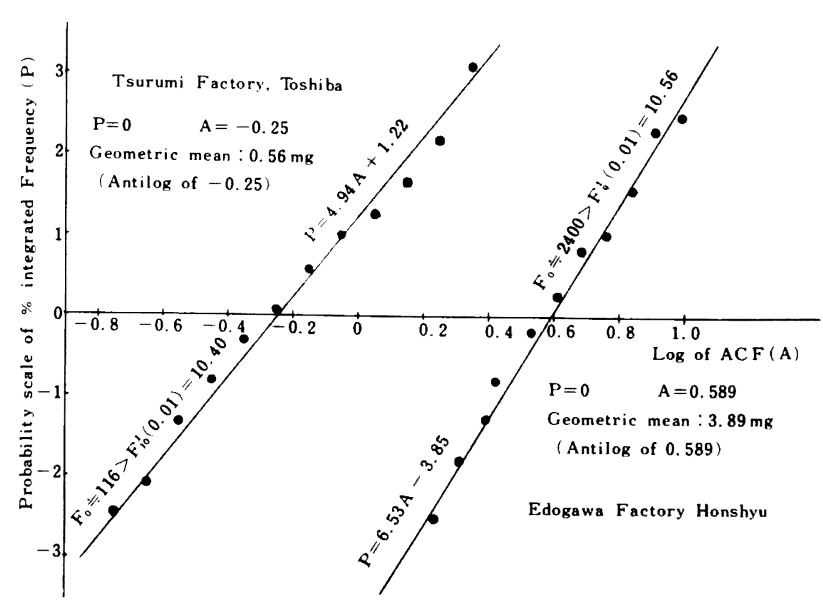

Fig. 2. Normal distribution of logarithmic ACF of two populations 
Table 4. Mean Ca depositions of two groups, heary calculus depositors and arerage people

\begin{tabular}{c|c|c}
\hline Population group & $\begin{array}{c}\text { Geometric mean and } \\
\text { standard deviation }\end{array}$ & $\begin{array}{c}\text { Iogarithmic mean and } \\
\text { log. standard deviation }\end{array}$ \\
\hline 140 heary depositors & $3.25 \mathrm{mg} \pm 1.42$ & $0.521+0.153$ \\
138 arerage people & $0.57 \mathrm{mg}+0.60$ & $0.247+0.202$
\end{tabular}

that average $\mathrm{Ca}$ amount of one population group should be geometric mean. Table 4 shows the averages and standard deviations of both groups obtained from logarithmic treatment.

\section{DISCUSSION}

To evaluate the method of some preventive measure, amount of calculus formed on the certain area for the certain period of time must be constant or in small deviation in every individual while investigating. Schroder and Marthaler ${ }^{21}$ concluded in their paper that a quantitative evaluation on the rate of calculus formation will be permitted by weighing the calculus formed on the foil within a certain period of time. The present method has obtained so similar conclusion that average deposition of $\mathrm{Ca}$ within first one month was almost the same to that of the second one month. These evidences suggest the existence of individual constancy of calculus deposition, or activity of calculus formation (ACF) of man. As to the ACF of one person, difference among each samples removed from a subject at different times must be smallest or the same. However, the present result as well as Schroeder and Marthaler's report contains some wider deviation in few cases. In the present method of sampling, scaling technique, collection from the particular small area like $1:$, and partial estimation of calculus amount by Ca measurement may be such source of error. The folien technique may also have unusual feeling on the top of the tongue which would change proper formation of calculus. Technique for the estimating ACF should be improved to minimize the deviation experienced at the indi. vidual subject. However, laboratory technique applied in this paper seems to be more objective than the clinical standards.

As shown in the results of trial 3, normal distribution of logarithmic $\mathrm{Ca}$ amount of each samples indicates that statistical treatment of the results must be done by the logarithmic calculation. This is the reason why geometric average was adopted throughout the paper.

Ca amount of the deposition on 11 was estimated apploximately at $70 \%$ of that of 3] - 3 area, and also 4 weeks deposition in $\mathrm{Ca}$ amount is about 4 times as much as that of 7 days deposition, but it is about $65 \%$ of that during 12 weeks. Depend on these results, Ca amount in the calculus deposited during a month was choosen for the determination of $\mathrm{ACF}$.

Because of poor information on the concept of ACF, it should be stressed that epidemiological study of ACF will promise to bring the more important knowledges to the preventive dentistry. 


\section{PART II. CILINICAL EVALUATION OF THE PREVENTIVE} EFFECT OF THE CALCULUS SPILINT

Besides of the dissolving effect of the supragingival calculus deposited on the teeth by means of a dentogingival splint, Onisi and $\mathrm{Kondo}^{22)}$ has found some additional clinical effects, reduction of disagreeable odor, dicrease of the bleeding and exudation of pus from pathological pocket, recovery of gingival color, and sometimes dissolution of subgingival calculus. In this part, clinical evaluation of the effect of dentogingival splint for the prevention of calculus formation was carried by the comparing ACF estimated before and after application of the splint.

\section{METHODS AND MATERIALS}

Fifty five adalts of Edogawa Factory, consisting of 14 females and 41 males, were adopted for the tests of preventive effect of the splint. Two types of the splint were
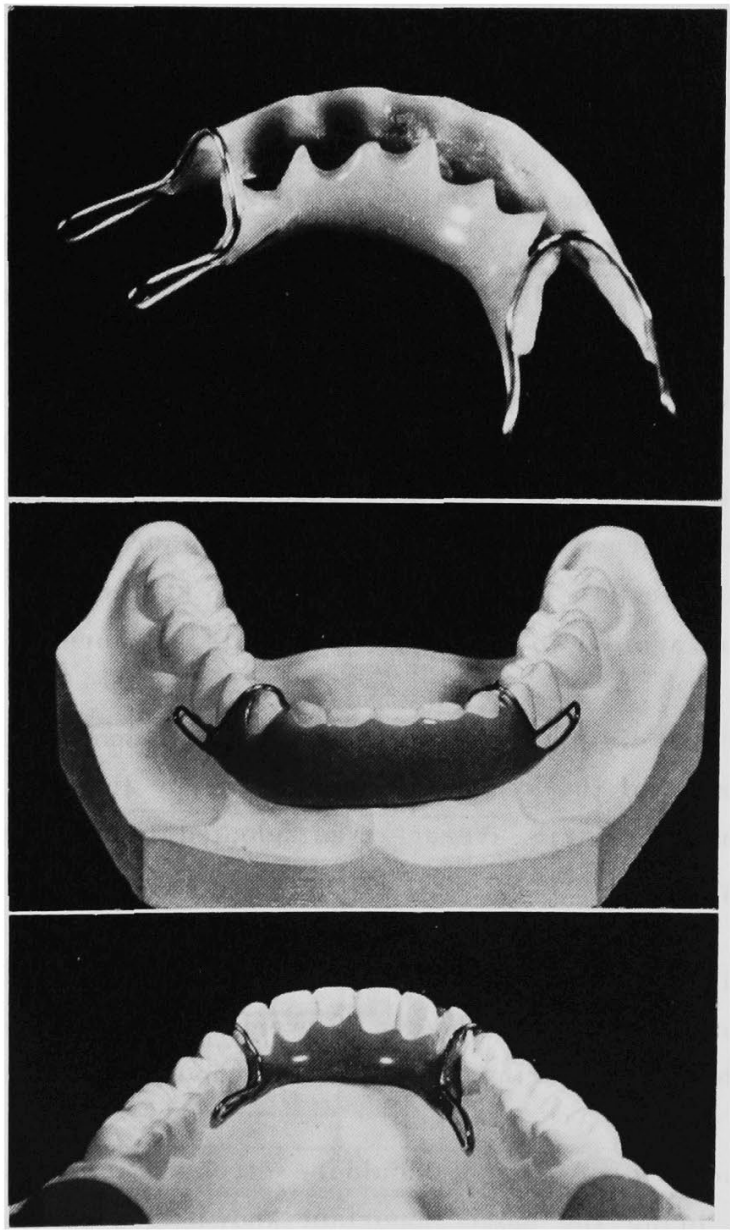

Fig. 3. Self curing resin splint

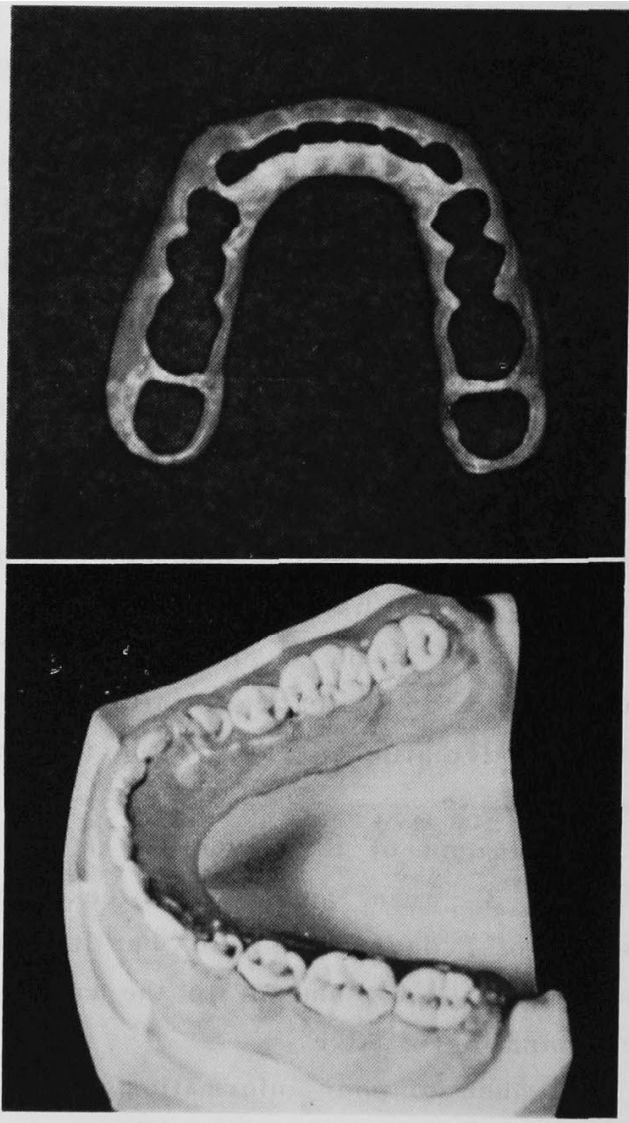

Fig. 4. Thermoplastic splint 
applied in three ways: first one is a self-curing resin splint covering the lower front, in the second, the same splint was used but additional alginate gel filled the space existing between splint and dentogingival surface, and the third one is a splint of elastic thermoplastic material covering whole mandibular dentogingival area. Figures 3 and 4 illustrate the resin- and the elastic thermoplastic splint.

For the test of the first resin splint, 28 patients, 7 females and 21 males, cooperated and in the second test for the resin splint with alginate filler, 21 patients, 6 females and 15 males, contributed to the obtaining its effect, and 24 patients, 9 females and 21 males, were used for test of the thermoplastic splint. Therefore, some patients were examined two or three different modes of application of the splints. In any way, the splints were adopted only during night time.

Every examinee first received thorough scaling, and after one month, his proper ACF, sighned Ao, was determined. Then the splint adopted for night time during one month. At the end of the test period, the affected ACF, sighned Asp, was determined. Preventive effect of the splint was estimated by comparing Asp to the initial Ao.

Based on the results of Kondo and Onisi, 19 samples of a mouth-full of gargled water for one minute have been collected from 19 subjects just before taking lunch at the day before application of the thermoplastic splint, and again 19 gargled waters were sampled from the same subjects of the splint in the same way. Number of Veillonella in the minor part of the gargled water was counted on the Rogosa's selective medium. ${ }^{26)}$ Due to easyer identification of the colonial appearance, Veillonella have been regarded as the better substitute of the Lactobacilli in the same specimen. The bulk of sediment in the major part of the gargled water was examined by centrifugation up to the constant volum at the certain rpm.

\section{RESULTS}

1. Examination on the influences of the splint on the Veillonella count and bulk of sediment

Wearing the splint for the night time did not cause any change of average population of Veillonella count and bulk of oral sediment as shown on the Table 5 . And lineal relation between Veillonella count and bulk of sedimet was noticed. The relation existing in the results obtained before wearing the splint was very close to that obtained from subjects wearing the splint, as shown in the Fig. 5.

\section{Reduction of $A C F$ by application of the splint}

Results from wearing the splint were summarized in the Table 6, showing that the thermoplastic splint was the most effective. Reductions of the ACF of three splints were all significant at probability level less than $p: 0.01$.

\section{DISCUSSION}

The growth promoting action of the small splint for the population of aciduric bacteria in the mouth has found by Onisi and Kondo.? And Onisi, Kondo and Horiuchi, ${ }^{28)}$ and 
Table 5. No influence of the splint on the Veillonella counts and bulk of sediments

\begin{tabular}{c|c|c}
\hline Time of sampling & $\begin{array}{c}\text { Veillonella count, mean } \\
\text { and standard deviation } \\
\text { (in log) }\end{array}$ & $\begin{array}{c}\text { Bulk of sediment, mean } \\
\text { and standard deviation } \\
\text { (in log) }\end{array}$ \\
\hline Before application & $6.849 \pm 0.585$ & $1.255 \pm 0.396$ \\
During application & $6.773 \pm 0.521$ & $1.187 \pm 0.327$
\end{tabular}

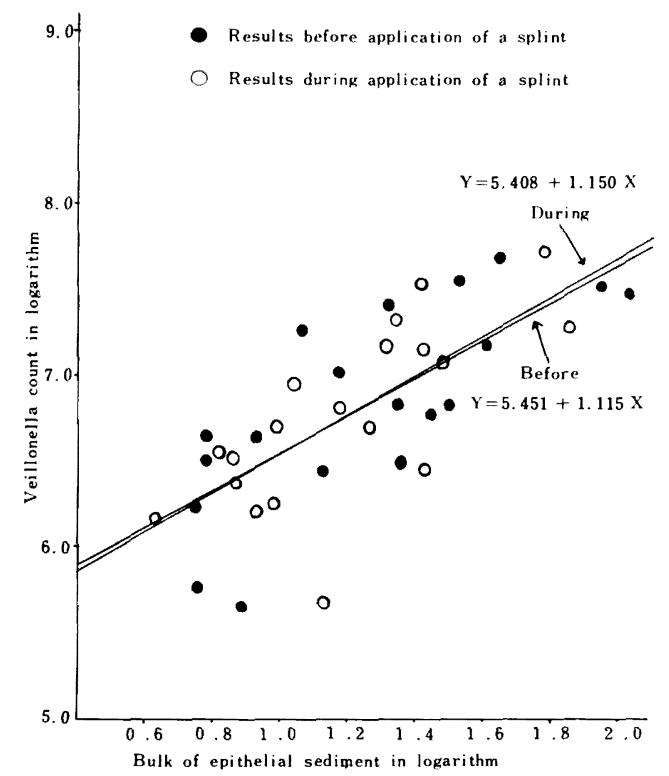

Fig. 5. No influence of the calculus splint upon the lineal relation between the bulk of epithelial sediment and Veillonella population

Table 6. Decrease of ACF after application of splints

\begin{tabular}{|c|c|c|c|c|c|c|c|}
\hline \multirow[t]{2}{*}{ Splints } & \multirow{2}{*}{$\begin{array}{c}\text { Number } \\
\text { of } \\
\text { subjects }\end{array}$} & \multicolumn{2}{|c|}{$\begin{array}{l}\text { Geometric } \\
\text { mean }(\mathrm{mg}) \\
\end{array}$} & \multicolumn{2}{|c|}{$\begin{array}{l}\text { Log. mean and } \\
\text { standard error }\end{array}$} & \multirow{2}{*}{$\begin{array}{c}\% \text { reduction } \\
{\left[\left(1-\frac{\log A s p}{\log A o}\right) \times 100\right.}\end{array}$} & \multirow{2}{*}{$\begin{array}{c}\text { Level of } \\
\text { significance } \\
\mathbf{p}: \\
\end{array}$} \\
\hline & & Ao & Asp & $\log \mathrm{Ao}$ & $\log$ Asp & & \\
\hline 1. Resin & 28 & 4.39 & 2.88 & $0.641 \pm 0.0288$ & $0.459 \pm 0.0319$ & 28.7 & $<0.01$ \\
\hline $\begin{array}{l}\text { 2. Resin with } \\
\text { alginate filler }\end{array}$ & 21 & 3.45 & 1.68 & $0.537 \pm 0.0613$ & $0.226 \pm 0.0255$ & 57.8 & $<0.01$ \\
\hline 3. Thermoplastic & 24 & 3.65 & 1.10 & $0.561 \pm 0.0355$ & $0.042 \pm 0.0590$ & 92.5 & $<0.01$ \\
\hline
\end{tabular}

Onisi and Takamori ${ }^{29)}$ have considered the role of the splint to trap such active substance appeared from the gingival crevice. Takamori ${ }^{30}$ has found that growth stimulating action in the normal saline which exclusively irrigated the dentogingival region under the splint and also hexose and pentose in the same solution. Recently Brill and Krassa, ${ }^{31)}$ Brill and Björn, ${ }^{32)} K^{2}{ }^{33)}$ Sueda $^{34)}$ and $\mathrm{Hara}^{35)}$ have reported their findings that tissue fluid has ap. peared in gingival pockets. Exudation of carbohydrates from gingiva may be regulated under local and systemic control. Trott ${ }^{59)}$ has claimed his opinion that presence of glycogen in the gingiva due to the metabolic peculiarity of epithelium, because of the lack of a blood supply. Inflammative process caused gluconeogenesis ${ }^{36)}$ and inflammative gingiva has often shown higher deposition of glycogen in its epithelial layer. ${ }^{37.38 .39)}$ Toganoh $^{40)}$ showed higher Lactobacillus count to be found in the cases of gingivitis than in the specimen taken from 
healthy mouths, pyorrhea and calculus depositor. Suenobu ${ }^{41)}$ has proved some relation between puberty gingivitis and Lactobacillus count in the mouth. Onisi and Kosuge ${ }^{42)}$ also showed definite correlation between desquamation and keratinization of oral mucosa and ovulation. Katsura and Onisi ${ }^{43)}$ recently found in thir unpublished results that streptococcal population increased at the middle phase of the menstrual cycle. Kondo et al ${ }^{25)}$ also found that the bulk of oral sediment in the gargled water has rised in parallel with the count of Lactobacilli, Streptococci and Veillonella in the same specimen. Based on the ecological concept, Onisi, Kondo and Takizawa ${ }^{44}$ gave the name, glycolytic layer, to the group of these organisms. Candida ${ }^{45)}$ and aerobic halophic Micrococcus count in the mouth ${ }^{46)}$ may also followed the population rise of the glycolytic members. Action of the certain glycolytic member may produce the accumulation of acid under anaerobic circumstance presented under the splint. (7) $^{\text {Decrease of }} \mathrm{pH}$ under the splint after growth of glycolytic layer may produce a circumstance difficult of calculus deposition. In two respects, trapping the growth promoting substance and enhancement of fermentation under the splint, tightness of the splint to the dentogingival surface may be the one of the important factors to obtain good result for the prohibition of the calculus formation. Thus it may happened in this paper that the elastic thermoplastic splint was the most effective, and besides application of alginate filler has reinforced function of the simple resin splint.

Another assumption of the role of the splint in its preventive effect may be found in the bacteriological aspect on the dental plaque. Wasserman, Mandel and Levy ${ }^{6)}$ introduced a technique for in vitro studying calcification of pre-calcified bacterial plaque and they pointed the similarity of calcification of the plaque to other calcifiable tissue. Ennever ${ }^{49)}$ demonstrated that filamentous organisms in plaque acquired intracellular insoluble mineral which was indicated to be calcium hydrooxyapatite by X-ray diffraction pattern. In general, aged bacteria accumulate $\mathrm{Ca}$ salt or Ca-compounds in their cells, whether they are bacterial spore ${ }^{50)}$ or aged non-sporulating cells in the resting stage. 51,52) Powell and Strange ${ }^{53)}$ and Powell ${ }^{54)}$ revealed that synthesis of dipicolinic acid by sporulating cells appeared invariably concurrent to increase of calcium in the cells of $B$. subtilis and $B$. cereus during sporulation and this dipicolinic acid was able to chelate strongly with calcium or heavy metals, but weakly with magnesium. The dicrease of free water content of the aged bacterial cell ${ }^{55)}$ may have some cooperative role on the calculus formation in the bacterial plaque. Takazoe and Nakamura ${ }^{19)}$ has found that cells containing the more metachromatic granule, chiefly consisting of polymetaphosphate, of Bacterionema matruchotii were the lesser calcifiable. Lindegren ${ }^{56)}$ has proposed that granule of metaphosphate in yeast cells, volutin granule, was functioning to be essential for division of chromosomes and supported the Wiame's view that metaphosphate may be a source of energy. Clinical evidences that under the partial plate or orthodontic appliances, ${ }^{57)}$ bacterial plaque has grown poor may enable the assumption that filamentous organisms to settle down on the tooth surface is kept young under the splint. Brushing tooth may remove the aged filamentous to prohibit the calculus formation. Kato ${ }^{58)}$ showed the absence of the bacterial plaque on the root surface at the bottom of deep pyorrhea pocket. Bacterial plaque may mainly composed by 
not strict anaerobes. Tightness of the splint would be required in this respect.

Increase of the Lactobacillus population under the splint may make entertain the missgiving onto decalcification of dental tissues. Actually, however, it has not experienced at numbers of long term adoption of the splint. In this connection. it should be noticed that the splint waering night time did not influence Veillonella population, a member of the glycolytic layer, in the mouth at day time. According to the results of Krause, Nickerson, and Perry,48) Onisi and Asaka,5) and Nemoto46) in the well composed bacterial plaque, final anaerobic fermentation products may be eliminated when atomospheric oxigen diffuse in and respiration of aerobic oral flora moved under the splint. The calculus splint, therefore, can be more promissing than the fear to decalcification. Additional merits observed by Onisi and Kondo ${ }^{22}$ ) were also found in the present study and it may. be due to the old concept in bacteriology, antiputrefactive action of Lactobacilli.

\section{SUMMARY}

Calcium amount in the deposit on clinical crown of $\overline{1 / 1}$ during one month will be considered to express the individual activity of supragingival calculus formation(ACF). It will be more reasonable that geometric mean is adopted in the case of statistical treatment of the results, when the test for some preventive measure against calculus formation will conduct with some population group.

Application of a dentogingival splint has been proved to be a new effective measure to prevent supragingival calculus formation. Eventhough the tightness of the splint depends upon the material and method to prepare it, it is the most important requirement to insure its effectiveness. Veillonella count was measured when it was withdrawn from the mouth, but the splint has no influence of their population at the time of sampling.

\section{ACKNOW LEDGEMENT}

Authors express their appreciation to Dr. Chiba, Honshu Paper Company, Dr. Suzuki, Toshiba Electric Company, and Dr. Sakai, Dr. Matsudaira, Dr. Shiozawa and Miss Takano for their clinical help.

\section{REFERENCES}

1. Yasuo Kanzawa: Experimental study on several calculus dissolving dentifrice. Nippon no Shikai, 1034, 1935. (In Japanese).

2. Jensen, A. L. : Use of dehydrated pancreas in oral hygiene, J. A. D. A., $59: 923,1959$.

3. Aleece, A. A. and Forscher, B. K. : Calculus reduction with a mucinase dentifrice. J. Period., 25 : 122, 1954.

4. Stewart, G. G.: Mucinase. A possible means of reducing calculus formation. J. Period., $23: 85,1952$.

5. Ennever, J. and Sturzenberger, O.P.: Inhibition of dental calculus formation by use of an enzyme chewing gum. J. Period., $32: 331,1961$.

6. Wasserman, B., Mandel, I. D. and Levy, B. M. : In vitro calcification of dental calculus. J. Period., $29: 144,1958$.

7. Lehr, W.: Die Nebenwirkung handels ueblicher Praeparate und Tinkturen zur Beseitigung der supragingivalen Zahnauflagerungen auf den Schmelz unserer Zaehne. Deut. Zahnarztl. Wochschr., 42:56, 1939. 
8. Bergve: Cited in Martiny's "Die Entstehung und Bekaempfung der Konkrementbildungen an den Zaehnen und in den Speicheldruesengaengen". II. Teil. Deut. Zahñarztl. Wochschr., 42: 998,1945 , and $1060,1939$.

9. Joffman, D. L., Shall ard, R. E. and Schaffer, E. M.: An in vitro attempt to inhibit calculus formation using an ion exchange resin. J. Period., $34: 344,1963$.

10. Schaffer, E. M., Schindler, C. W. and Mchugh, R. B.: The effect of two ion exchange resins on the inhibition of calculus like deposits in vitro. J. Period., $35: 296,1964$.

11. Maeda, J. and Kawashima, T. : Dental application of ethylen diamin tetraacetate(EDTA). Shikai Tenbo, $11: 602$, 1954. (In Japanese).

12. Kerr, D. A. and Field, H. : Sodium hexametaphosphate as an aid in the treatment of periodontal disease. J. D. Res., $23: 313,1941$.

13. Tamura, Y.: Influence of Zeolite upon dissolution of $\mathrm{Ca}$ in calculus. Shika Gakuho, $57: 1,1957$. (In Japanese).

14. Rapp, G. W. : The biochemistry of oral calculus. II. The presence of carbonic anhydrase in human saliva. J. A. D. A., $33: 191,1946$.

15. Hartner, F. and Rheinwald, U. : Sulfo-Rizinoleate als Zahnstein-Entfernungsmittel. Deut. Zahnarztl. Wochschr., $40: 312,1937$.

16. Sanders, W. E. and Robinson, H. B. G. : Effect of tooth brushing on deposition of calculus. J. Period., $33: 386,1964$.

17. Dossenbach, W.F. and Muehlemann, H.R.: Effect of penicillin and ricinoleate on early calculus formation. Helv. Odont. Acta., $5: 25,1961$.

18. Schroeder, H. E. : Quantitative In-vivo-studie mit Zahnsteinhemmstoffen. Schw. Monatschr.f. Z., 72 : 399, 1962.

19. Takazoe, I. and Nakamura, T. : The relation between metachromatic granules and intracellular calcification of Bacterionema matruchotii. Bull. Tokyo Dent. Coll., $6: 29,1964$.

20. Ennever, J., Sturzenberger, O. P. and Radike, A. W. : The calculus surface index method for scoring clinical calculus studies. J. Period., $32: 54,1961$.

21. Schroeder, H. E. and Marthaler, T.M.: Normierte Folien als Zahnsteintraeger. Schw. Monatschr. f. Z., $71: 596,1961$.

22. Onisi, M. and Kondo, W. Biological control of the dental calculus. Proceding of the 1st Asian Dental Congress, Tokyo, Oct. 15, 1955.

23. Toganoh, M. and Onisi, M. : Unpublished data.

24. Glock, G. E. and Murray, M. M. : Chemical investigation of salivary calculus. J. D. Res., $17: 257$, 1938.

25. Kondo, W. and Onisi, M. : Significant correlations between the bulk of the desquamated epithelium, Lactobacillus, Streptococcus, and Veillonella count of the human mouth., J. J. Microbiol., $6: 41$, 1962.

26. Rogosa, M. : A selective medium for the isolation and enumeration of the Veillonella from the oral cavity. J. Bact., $72: 533,1956$.

27. Onisi, M. and Kondo, W. : Establishing an environment for growth of aciduric bacteria in the oral cavity. J. D. Res., $35: 596,1956$.

28. Onisi, M., Kondo, W. and Horiuchi, I. : Role of dentogingival splint of acrylic resin for the increase of Lactobacillus in the mouth. Bull. Tokyo Med. Dent. Univ., $7: 157,1960$.

29. Onisi, M., Takamori, K.: Role of dental and gingival splint in the Lactobacillus count of the mouth. Bull. Tokyo Med. Dent. Univ., 12:169, 1965.

30. Takamori, K. : The growth stimulating factors for Lactobacillus appeared in tissue fluid from gingival crevice. Bull. Tokyo Med. Dent. Univ., $10: 533,1963$.

31. Brill, N. and Krassa, B. : The passage of tissue fluid into the chemically healthy gingival pocket. Acta Odont. Scand., $16: 233,1958$.

32. Brill, N. and Bjoern, M.: Passage of tissue fluid into human gingival pockets. Acta. Odont. Scand., $17: 11,1958$. 
33. Konno, H. : The paperchromatographic analysis of exudate from the periodontal pocket. J. J. Stomat. Soc., $27: 392$, 1960. (In Japanese).

34. Sueda, T.: On the tissue fluid flowing out in gingival pocket. Total weight and ninhydrin positive substance. J. J. Stomat. Soc., $29: 269,1962$. (In Japanese).

35. Hara, K.: Carbohydrate in pus and exudate from gingival pockets. J. J. Stomat. Soc., $30: 239.1963$. (In Japanese).

36. Menkin, V.: Gluconeogenesis and cellular injury. A further inquiry into the mechanism involvedin diabetes enhanced by inflammation. Amer. J. Physiol., $138: 396,1943$.

37. Dewar, M. R. : Observations on the composition and metabolism of normal and inflamed gingivae. J. Periol., $26: 29,1955$.

38. Forscher, B.K., Paulsen, A.G. and Hess, W.C.: The pH of the periodontal pocket and the glycogen content of the adjacent tissue. J. D. Res., $33: 444,1954$.

39. Forscher, B.K., Paulsen, A. G. and Hess, W. C. : Glycogen content of periodontal tissue. II. Correlation with tyrosine content. J. D. Res., $34: 144,1955$.

40. Toganoh, M. : Numerical responces of aciduric bacteria to dental states in the mouth. J. J. Stomat. Soc., $23: 93$, 1956. (In Japanese).

41. Suenobu, K. : Relation among puberty, menstruation and aciduric bacteria in the mouth. J. J. Stomat. Soc., $26: 512$, 1959. (In Japanese).

42. Onisi, M. and Kosuge, H. : A newly developed method for the estimation of the oral keratinization and some results from its application on young females. J. J. of Dent. Health. 15:73. 1965. (In Japanese).

43. Katsura, T. and Onisi, M. : Population rise of oral streptococci at the middle phase of the menstrual cycle. (unpublished).

44. Onisi, M., Kondo, W. and Takizawa, S. : Intraoral populations of Fusobacteria, Lactobacilli and Streptococci. J. J. Microbiol., $5: 117,1961$.

45. Onisi, M. and Asaka, K. : Relation between Candida and Lactobacillus count in the mouth. J. J. Dent. Health, $12: 168,1962$. (In Japanese).

46. Nemoto, H. : Ecological studies on the oral flora of school children. J. J. Stomat. Soc., $26: 1187$. 1959. (In Japanese).

47. Onisi, M., Kondo, W., Horiuchi, I. and Uchiyama, Y. : Preliminary report on the oxidation-reduction potentials obtained on surfaces of gingiva and tongue and in an interdental space. Bull. Tokyo Med. Dent. Univ., $7: 161,1960$.

48. Kraus, F. W., Nickerson, J. F., Perry, W. I. and Walker, A. P. : Peroxide and peroxidogenic bacteria in human saliva. J. Bact., $73: 727,1957$.

49. Ennever, J. : Intracellular calcification by oral filamentous microorganisms. J. Period., $31: 304$, 1960.

50. Curran, H.R., Brunstetter, B. C. and Myers, A. T. : Spectrochemical analysis of vegetative cells and spores of bacteria. J. Bact, $45: 485,1943$.

51. Onisi, M., Takagaki, M. and Kato, T. Studies on the mechanism of resistance of bacteria. V. The decrease of electrical conductivity of bacterial suspensions in accordance with the physiological maturation. Y-Hama Med. Bull., $5: 197,1954$.

52. Onisi, M., Nakamura, T., Katayama, H. and Kanai, M. : Studies on the mechanism of resistance of bacteria. VIII. Chemical aspect on the decreasing electroconductivity of bacterial cell suspension during aging. Bull. Tokyo Med. Dent. Univ., 4:189, 1957.

53. Powell, J. F. and Strange, R. E. : Biochemical changes occuring during sporulation in Bacillus species. Biochem. J., $63: 661,1956$.

54. Powell, J.F.: Isolation of dipicolinic acid (Pyridine-2:6-dicarboxylic acid) from spores of Bacillus megatherium. Biochem. J., $54: 210,1953$.

55. Onisi, M.: Studies on the mechanism of resistance of bacteria. III. The permeability of bacterial cell-membrane and the free water in the bacterial body. J. J. Bact., $5: 361,1950$. (In Japanese).

56. Lindegren, C. C.: Function of volutin (metaphosphate) in mitosis. Nature, 159:63, 1947. 
57. Onisi, M., Kondo, W., Katayama, K., Horiuchi, I., Nemoto, H. and Uchiyama, K.: Influences of orthodontic appliances upon the population of oral aciduric bacteria and range of bacterial plaque on the tooth surface. J. J. Stomat. Soc., $26: 249$, 1959. (In Japanese).

58. Kato, T. : Bacterial plaque on the tooth surface. J. J. Stomat. Soc., $26: 249$, 1959. (In Japanese).

59. Trott, J.R.: The presence and distribution of glycogen in the gingiva. Austr. Dent. J., 2831957.

歯石副子の使用による歯肉縁上歯石沈着の予防

大西正男大谷広明

東京医科歯科大学歯学部予防歯科学教室

電石沈着の予防は多くの可能性因子によって試めさ れた。しかし予防効果の判定法を明確に定義したもの が少かった。歯石沈着の除去作用のあった歯石副子に よる予防効果を実験するに先だって、判定法が試験さ れた。

同一群の人々について同一期間内に貯まる沈着物中 の $\mathrm{Ca}$ 量を 2 回測定したところ、2 回の平均值は等し かったことから，歯肉縁上歯石沈着には歯石形成活動 度 ( ACF) のあることを知った。これを測定するには， 一度歯石除去をした後、1 月月後に下顎中切歯冠上の 沈着物をシックル型スケーラーで出血をさせないよう に採取、し、この中の Ca 量で行った。また、多人数の ACFは对数值をとるとき正規分布をすることも判っ
たので, 集団を代表するものは幾何平均であることを 知った。

即立レジン製の副子、即充レジン製副子にアルジネ ートゲルを加えて雪面との吵間を填めたもの、サモプ ラスチック製副子の三種を夜間だけ使用し，使用前の ACFに対して, 使用によるACFの減少率を測定し た。いずれの副子も有意水準 $1 \%$ 以下で A C F を減少 していたが, 最も有効であったのは、サモプラスチッ ク製副子で、次はレシン副子にアルジートを併用し たものであった。

使用期間中の昼食前のVeillonella 菌数と含嗽液中 の沈渣量を測定したが、どちらにも副子使用による影 響がみられなかった。 